\title{
Layanan Pendidikan Anak Berkebutuhan Khusus Dengan Gangguan Emosi dan Perilaku
}

\author{
Ni Luh Gede Karang Widiastuti \\ Program Studi Pendidikan Guru Sekolah Dasar, Universitas Dwijendra, Denpasar \\ e-mail: karangwidhi@gmail.com
}

\begin{abstract}
Abstrak
Penelitian ini bertujuan untuk menganalisis karakteristik, faktor-faktor penyebab gangguan, pendekatan yang bisa dilakukan untuk mengatasi dan model layanan pendidikan bagi anak berkebutuhan khusus dengan gangguan emosi dan perilaku. Penelitian ini dilatarbelakangi oleh berbagai kasus yang terjadi berkaitan dengan keterbatasan pendidikan yang diperoleh anak berkebutuhan khusus, bahkan tidak sedikit anak tersebut mengalami perlakuan diskriminatif. Metode penelitian bersifat deskriptif dengan teknik pengumpulan data berupa studi literatur dari berbagai referensi yang relevan dengan gejala yang diamati. Data yang terkumpul dianalisis secara deskriptif kualitatif sehingga dapat dilihat variasi karakteristik dan model layanan pendidikan bagi anak berkebutuhan khusus dengan gangguan emosional dan perilaku. Hasil penelitian menunjukkan bahwa anak dengan gangguan emosi dan perilaku memiliki karakteritik meliputi: inteligensi dan prestasi belajar, karakteristik sosial dan emosi dan immature, withdrawl behavior. Model layanan pendidikan bagi anak berkebutuhan khusus dengan gangguan emosi dan perilaku dapat dikelompokkan menjadi 3 yaitu layanan pendidikan segregrasi, layanan pendidikan terpadu/integrasi, dan pendidikan inklusi.
\end{abstract}

Kata kunci: Layanan Pendidikan, Gangguan Emosi Perilaku

\begin{abstract}
The research aims to determine the characteristics, factors that cause disruption, approaches that can be taken to overcome, and educational service models for children with special needs with emotional and behavioral disorders. This research is motivated by a variety of cases that occur related to the limitations of education obtained by children with special needs, even some of the children experience discriminatory treatment. The research method is descriptive with data collection techniques in the form of literature studies from various references relevant to the symptoms observed. The collected data were analyzed descriptively qualitatively so that variations in characteristics and models of educational services can be seen for children with special needs with emotional and behavioral disorders. The results showed that children with emotional and behavioral disorders have characteristics including intelligence and learning achievement, social and emotional characteristics and immature, withdrawal behavior. The model of educational services for children with special needs with emotional and behavioral disorders can be divided into 3, segregation education services, integrated education services/integration, and inclusive education.
\end{abstract}

Keywords: Education Service, Emotional Behavioral Disorders

\section{Pendahuluan}

Pendidikan merupakan sebuah proses transformasi pengetahuan menuju ke arah perbaikan, penguatan dan penyempurnaan semua potensi manusia. Oleh karena itu, pendidikan tidak mengenal ruang dan waktu, berlangsung sepanjang hayat dan bisa dilakukan dimana saja dan kapan saja oleh manusia serta mampu melakukan proses kependidikan (life long education) (Arriani, 2017; Fridayanthie, 2016a; Murniarti \& Anastasia, 2016; Rahayu, 2015).

Semua warga negara berhak mendapatkan pendidikan termasuk di dalamnya anak berkebutuhan khusus. Sebagaimana yang dijelaskan dalam Undang-undang Nomor 20 tahun 2003 tentang Sistem Pendidikan Nasional pasal 5 ayat (2) yang berbunyi Warga Negara yang memiliki kelainan fisik, emosional, mental, intelektual, dan/atau sosial berhak memperoleh pendidikan khusus". Pemerintah telah memfasilitasi pendidikan bagi anak berkebutuhan khusus dengan adanya lembaga pelayanan pendidikan bagi anak berkebutuhan khusus, salah satunya anak dengan gangguan emosi dan perilaku. 
Anak berkebutuhan khusus dengan gangguan emosi dan perilaku memiliki karakteristik yang komplek dan seringkali perilakunya juga dilakukan oleh anak-anak lain seperti perilaku tidak patuh, perkelahian, perusakkan, pengucapan kata-kata kotor dan tidak senonoh, senang memerintah, berperilaku kurang ajar, serta menyendiri. Karakteristik yang komplek dan seringkali mirip dengan anak seusianya menyebabkan anak dengan gangguan emosi dan perilaku sulit untuk dideteksi sehingga seringkali terjadi kesalahan dalam pemberian layanan pendidikan yang sesuai dengan kekhususan yang dimiliki anak (Indonesia \& Barat, 2019; Persada \& Efendi, 2018; Wati, 2014).

Selain itu, di lapangan anak berkebutuhan khusus dengan gangguan emosi dan perilaku sering mendapat perlakuan diskriminatif dari orang lain. Bahkan untuk menerima pendidikan saja mereka sulit. Beberapa sekolah regular tidak mau menerima mereka sebagai siswa. Alasannya guru di sekolah tersebut tidak memiliki kualifikasi yang memadai untuk membimbing anak berkebutuhan khusus. Terkadang sekolah khusus letaknya jauh dari rumah mereka, sehingga banyak anak berkebutuhan khusus yang tidak mengenyam pendidikan.

Berdasarkan permasalahan tersebut, pemerintah perlu menyediakan layanan pendidikan bagi anak berkebutuhan khusus dengan gangguan emosi dan perilaku (Agustin, 2017; Nugroho \& Mareza, 2016; rafikayati \& Jauhari, 2018), baik pada jenjang pendidikan dasar maupun pendidikan menengah termasuk di dalamnnya sistem pembelajaran, fasilitas yang mendukung, maupun peran guru yang sangat penting untuk memberikan motivasi dan arahan yang bersifat membangun (Dermawan, 2018; Wathoni, 2013). Hal ini sesuai dengan Peraturan Pemerintah Nomor 17 tahun 2010 tentang Pengelolaan Penyelenggaraan Pendidikan pasal 133. Dalam peraturan tersebut dijelaskan bahwa pemerintah memberikan kesempatan bagi anak berkebutuhan khusus, salah satunya dengan gangguan emosi dan perilaku untuk dapat memperoleh layanan pendidikan yang sama dengan siswa reguler. Fokus permasalahan yang ingin dikaji dalam hal ini adalah karakteristik, faktor-faktor penyebab gangguan, pendekatan yang bisa dilakukan untuk mengatasi dan model layanan pendidikan digunakan untuk membantu anak berkebutuhan khusus dengan gangguan emosi dan perilaku dalam belajar dan mengembangkan kreativitasnya.

\section{Metode}

Penelitian yang dilaksanakan bersifat deskriptif dengan teknik pengumpulan data berupa studi literatur dari berbagai referensi yang relevan dengan gejala yang diamati yaitu pada subjek anak berkebutuhan khusus dengan gangguan emosional dan perilaku. Data yang terkumpul dianalisis secara deskriptif kualitatif sehingga dapat dilihat variasi karakteristik dan model layanan pendidikan bagi anak berkebutuhan khusus dengan gangguan emosional dan perilaku. Sehingga dengan mengetahui karakteristik dan variasinya maka dapat dilakukan pelayanan pendidikan yang tepat pada setiap gejala yang dialami.

\section{Hasil dan Pembahasan}

\section{Pengertian Gangguan Emosi dan Perilaku}

Gangguan emosional dan perilaku (Emotional And Behavioral Disorder) di Indonesia dikenal dengan istilah Tunalaras. Emotional And Behavioral Disorders (EBD) atau gangguan emosional perilaku mengacu pada suatu kondisi dimana tanggapan perilaku atau emosional seorang individu di sekolah sangat berbeda dari norma-norma anak lain yang umumnya diterima, sesuai dengan usia, etnis, atau budaya yang mempengaruhi secara berbeda kinerja pendidikan di wilayah seperti perawatan-diri, hubungan sosial, penyesuaian pribadi, kemajuan akademis, perilaku di ruang kelas atau penyesuaian terhadap pekerjaan (Anggriana \& Trisnani, 2016; Fridayanthie, 2016b; Noviandari \& Huda, 2018). Simptom gangguan emosi dan perilaku biasanya dibagi menjadi dua macam, yaitu externalizing behavior dan internalizing behavior. Externalizing behavior memiliki dampak langsung atau tidak langsung terhadap orang lain, contohnya perilaku agresif, membangkang, tidak patuh, berbohong, mencuri, dan kurangnya kendali diri. Internalizing behavior mempengaruhi anak dengan berbagai macam gangguan seperti kecemasan, depresi, menarik diri dari interaksi 
sosial, gangguan makan, dan kecenderungan untuk bunuh diri. Kedua tipe tersebut memiliki pengaruh yang sama buruknya terhadap kegagalan dalam belajar di sekolah (Hallahan \& Kauffman,1988; Eggen \& Kauchak,1997).

Oktaviana \& Wimbarti (2014) menjelaskan bahwa gangguan tingkah laku adalah gangguan yang ditandai dengan pola tingkah laku disosial, agresif atau menentang, yang berulang dan menetap. Perilaku ini dalam bentuk ekstremnya berupa pelanggaran berat dari norma sosial yang terdapat pada anak seusia itu, dan karena itu pelanggarannya bersifat menetap dan lebih parah daripada kenakalan anak atau sikap memberontak remaja pada lazimnya. Penilaian tentang adanya gangguan tingkah laku perlu mempertimbangkan tingkat perkembangan anak. Gangguan emosi dan perilaku juga diartikan sebagai anak yang mengalami kesulitan dalam penyesuaian diri dan bertingkah laku tidak sesuai dengan norma-norma yang berlaku dalam lingkungan kelompok usia maupun masyarakat pada umumnya sehingga merugikan dirinya maupun orang lain, dan karenanya memerlukan pelayanan pendidikan khusus demi kesejahteraan dirinya maupun lingkungannya (http://www.ditplb.or.id, 2006).

\section{Karakteristik Anak dengan Gangguan Emosi dan Perilaku}

Heward \& Orlansky (1988) dalam Sunardi (1996) mengatakan seseorang dikatakan mengalami gangguan perilaku apabila memiliki satu atau lebih dari lima karakteristik berikut dalam kurun waktu yang lama, yaitu:ketidakmampuan untuk belajar yang bukan disebabkan oleh faktor intelektualitas, alat indra maupun kesehatan, ketidakmampuan untuk membangun atau memelihara kepuasan dalam menjalin hubungan dengan teman sebaya dan pendidik, tipe perilaku yang tidak sesuai atau perasaan yang di bawah keadaan normal, sudah terbawa suasana hati (emosi labil), ketidakbahagiaan, atau depresi kecenderungan untuk mengembangkan simtom-simtom fisik atau ketakutan-ketakutan yang diasosiasikan dengan permasalahan-permasalahan pribadi atau sekolah.

Lebih lanjut, Hallahan \& Kauffman (1988) menjelaskan tentang karakteristik anak dengan gangguan perilaku dan emosi, yaitu inteligensi dan prestasi belajar. Hallahan dan Kauffman (1988) menemukan bahwa anak-anak dengan gangguan ini memiliki inteligensi di bawah normal (sekitar 90) dan beberapa di atas bright normal. Dibandingkan dengan distribusi normal inteligensi, kebanyakan anak dengan gangguan emosional dan tingkah laku berada pada kategori slow learner dan ketidakmampuan intelektual ringan (mild intellectual disability). Kebanyakan anak yang memiliki gangguan emosional dan tingkah laku juga merupakan anak yang tidak berprestasi (underachiever) disekolahnya.

Kemudian, karakteristik sosial dan emosi. Agresif, acting-out behavior (externalizing)

Conduct disorder (gangguan perilaku) merupakan permasalahan yang paling sering ditunjukkan oleh anak dengan gangguan emosi atau perilaku (Awwad, 2015; Aziz, 2014). Perilaku-perilaku tersebut seperti memukul, berkelahi, mengejek, berteriak, menolak untuk menuruti permintaan orang lain, menangis, merusak, vandalisme, memeras yang apabila terjadi dengan frekuensi tinggi maka anak dapat dikatakan mengalami gangguan. Anak normal lain mungkin juga melakukan perilaku-perilaku tersebut tetapi tidak secara impulsif dan sering anak dengan conduct disorder.

\section{Immature, withdrawl behavior (internalizing)}

Anak dengan gangguan ini, menunjukkan perilaku immature (tidak matang atau kekanak-kanakan) dan menarik diri. Mereka mengalami keterasingan sosial, hanya mempunyai beberapa orang teman, jarang bermain dengan anak seusianya, dan kurang memiliki keterampilan sosial yang dibutuhkan untuk bersenang-senang. Beberapa diantara mereka mengasingkan diri untuk berkhayal atau melamun, merasakan ketakutan yang melampaui keadaan sebenarnya, mengeluhkan rasa sakit yang sedikit dan membiarkan "penyakit" mereka terlibat dalam aktivitas normal. Ada diantara mereka mengalami regresi yaitu kembali pada tahap-tahap awal perkembangan dan selalu meminta bantuan dan perhatian, dan beberapa diantara mereka menjadi tertekan (depresi) tanpa alasan yang jelas. 
Penelitian mengenai status sosial dari siswa regular sekolah dasar dan lanjutan pertama menunjukkan bahwa anak yang memiliki gangguan emosional dan tingkah laku ditolak oleh lingkungannya. Hubungan antara gangguan emosional dan tingkah laku dengan gangguan komunikasi cukup jelas. Anak atau remaja dengan gangguan emosional dan tingkah laku memiliki kesulitan yang besar dalam memahami dan menggunakan bahasa dalam lingkungan sosialnya. Secara umum karakteristik sosial dan emosional anak dengan gangguan emosional dan tingkah laku, adalah tingkah laku yang tidak terarah (tidak patuh, perkelahian, perusakan, pengucapan kata-kata kotor dan tidak senonoh, senang memerintah, berperilaku kurang ajar); gangguan kepribadian (merasa rendah diri, cemas, pemalas, depresi, kesedihan yang mendalam, menarik diri dari pergaulan); tidak matang atau tidak dewasa dalam sikap (pasif, kaku dalam bergaul, cepat bingung, perhatian terbatas, senang melamun, berkhayal); pelanggaran sosial (terlibat dalam aktivitas geng, mencuri, membolos).

Bower (1981) mengungkapkan bahwa terdapat lima komponen anak dengan hambatan emosional atau kelainan perilaku, antara lain: tidak mampu belajar bukan disebabkan karena faktor intelektual, sensori atau kesehatan; tidak mampu untuk melakukan hubungan dengan baik dengan teman dan guru; bertingkah laku atau memiliki perasaan yang tidak sesuai; secara umum, mereka selalu dalam keadaan ervasive dan tidak menggembiarkan atau depresi; bertendensi ke arah simptom fisik, seperti merasa sakit, atau ketakutan berkaitan dengan orang lain, atau dengan permasalahan di sekolah.

\section{Faktor-faktor Penyebab Gangguan Emosi dan Perilaku}

Beberapa faktor yang menyebabkan terjadinya gangguang emosi dan perilaku (Rohmawati, 2017) yaitu faktor biologi, faktor lingkungan atau keluarga, faktor sekolah, dan faktor masyarakat. Beberapa penyebab biologis telah ditemukan berhubungan dengan gangguan emosi dan perilaku tertentu. Contohnya termasuk anak-anak yang lahir dengan sindrom alkohol janin, yang menunjukkan masalah dalam pengendalian impuls dan hubungan interpersonal yang dihasilkan dari kerusakan otak. Malnutrisi dapat juga menyebabkan perubahan perilaku dalam penalaran dan berpikir. Selain itu, kelainan seperti skizofrenia mungkin memiliki dasar genetik.

Keluarga sangat penting dalam perkembangan anak-anak. Keluargalah peletak dasar perasaan aman pada anak, dalam keluarga pula anak memperoleh pengalaman pertama mengenai peasaan dan sikap sosial. Aspek-aspek yang berkaitan dengan masalah gangguan emosi dan tingkah laku, yaitu: (a) Penerapan pola asuh yang tidak konsisten dan kesalahan dalam penerapan disiplin, (b) Keterlibatan pihak ketiga yang ekstrim berbeda dalam pendidikan anak, (c) Penolakan dan pengabaian dari orangtua, (d) Orangtua atau orang dewasa menjadi model negatif bagi anak, (e) Kualitas rumah tangga, (f) Kematian salah satu orangtua yang memicu stres pada single parent, (g) Orangb tua dan anggota keluarga yang tidak dapat memenuhi kebutuhan anak, (h) Status sosial ekonomi keluarga, (i) Perlakuan orangtua yang tidak adil, (j) Harapan orangtua yang tidak realistik, dan (k) Hukuman fisik yang berlebihan. Disisi lain, interaksi yang sehat seperti kehangatan dan responsif, disiplin konsisten dengan panutan, dan perilaku yang mengharapkan penghargaan dapat sangat meningkatkan perilaku positif pada anak-anak.

Sekolah merupakan lingkungan kedua setelah keluarga yang mempengaruhi langsung terhadap perkembangan anak dan guru di sekolah juga bertanggungjawab dalam pendidikan anak. Lingkungan sekolah juga merupakan tempat berkembangnya penyimpangan tingkah laku anak. Beberapa sikap pihak sekolah yang tidak mendukung perkembangan positif pada anak, antara lain: (a) Disiplin dan tata tertib yang terlalu kaku, (b) Inkonsistensi pelaksanaan disiplin dan tata tertib, (c) Tuntutan yang terlalu berlebihan terhadap prestasi anak, (d) Kepribadian guru yang negatif, (e) Perlakuan guru yang tidak adil terhadap siswa, dan (f) Kemampuan manajemen waktu guru yang rendah. Disisi lain, interaksi positif dan produktif guru dan anak dapat meningkatkan pembelajaran anak dan perilaku sekolah yang sesuai serta memberikan dukungan ketika anak mengalami masamasa sulit. 
Masalah masyarakat, seperti kemiskinan ekstrim disertai dengan gizi buruk, keluarga yang tidak berfungsi, berbahaya dan lingkungan yang penuh kekerasan, dan perasaan putus asa, dapat mengakibatkan atau memperburuk gangguan emosi atau perilaku. Kita tidak boleh melupakan contoh anak muda yang telah selamat dari situasi yang mengerikan dan tumbuh menjadi orang dewasa yang sehat. Kita belajar dari individual yang ulet ini bahwa lingkungan yang merugikan tidak tak terhindarkan untuk menyebabkan kesulitan emosional atau perilaku.

\section{Pendekatan dalam Usaha Mengatasi Anak dengan Gangguan Emosi dan Perilaku}

Beberapa pendekatan yang dapat dilakukan dalam usaha mengatasi permasalahan anak dengan gangguan emosi dan perilaku yaitu pendekatan biomedis, pendekatan psikodinamik, pendekatan Pendidikan, dan pendekatan ekologi (Khusus et al., 2015; Nuraini, 2013; Praptiningrum, 2012; Rahayu, 2015). Pendekatan ini berusaha memandang dan memperlakukan anak dengan gangguan emosi dan perilaku dari sudut pandang ilmu kedokteran. Pendekatan ini tentu saja ditekankan pada obat dan penanganan secara medis. Orangtua dan guru dapat berkolaborasi dengan ahli medis atau dokter atau psikiater guna melakukan treatment pengobatan kepada anak sehingga siswa mendapat penanganan medis. Pendekatan ini digunakan untuk anak dengan gangguan emosi dan perilaku yang mengalami ketunalarasan karena cedera neurologis.

Pendekatan psikodinamik menitikberatkan pada segi psikologis anak. Pendekatan ini digunakan untuk mengatasi kelainan emosi. Strateginya adalah memahami dan memecahkan masalah yang difokuskan pada penyebab-penyebab hambatan yang dialami siswa. Biasanya para ahli yang melakukan pendekatan ini adalah konselor, psikolog, psikiater, dan atau pekerja sosial. Guru dapat juga menjadi bagian dari tim terapi yang menggunakan pendekatan psikodinamik.

Pendekatan Perilaku

Pendekatan perilaku atau modifikasi perilaku adalah usaha untuk mengubah perilaku yang merupakan problematika sosial dan personal bagi anak. Tujuannya adalah menghilangkan perilaku yang menjadi hambatan dan menggantinya dengan perilaku yang lebih layak secara sosial. Peran orangtua dan guru sangat penting karena lebih banyak menghabiskan waktu dengan anak.

Anak dengan gangguan emosi dan perilaku kurang mampu berkonsentrasi yang berakibat mereka juga kurang dapat mengikuti pembelajaran dengan baik. Program pengajaran yang tertata rapi dengan harapan-harapan jelas, dan rancangan indikator ketercapaian tujuan pembelajaran yang jelas dipercaya dapat meningkatkan prestasi anak dengan gangguan emosi dan perilaku. Kuncinya ada pada pembentukan suasana belajar yang baik, kondusif, dan ramah yang harus menjadi prioritas guru.

Pendekatan ini menitikberatkan pada faktor-faktor dan tekanan-tekanan dalam masyarakat. Usaha pada pendekatan ini difokuskan pada pengaruh interaksi lingkungan terhadap anak, sehingga pendekatan ini menekankan usaha kolaborasi antar keluarga, sekolah, teman, maupun lingkungan masyarakat.

\section{Model Layanan Pendidikan Bagi Anak Berkebututuhan Khusus dengan Gangguan Emosi dan Perilaku}

Dalam menentukan model layanan pendidikan yang sesuai maka identifikasi sangat penting dilakukan oleh seorang guru khususnya guru di sekolah dasar dalam menemukenali keberadaan anak dengan gangguan emosi dan perilaku. Identifikasi juga menjadi kunci keberhasilan proses pendidikan anak. Dalam program pendidikan, kegiatan identifikasi anak dengan kebutuhan khusus memiliki lima fungsi yaitu penjaringan (screening), yaitu menandai gejala anak dengan gangguan emosi dan perilaku di lingkungan kelas atau sekolah dengan menggunakan alat identifikasi yang telah ditetapkan, sehingga akan dapat dibedakan antara anak dengan gangguan emosi dan perilaku dengan siswa-siswa normal atau berkebutuhan khusus lain.

Pengalihtanganan (referal), yaitu menetapkan apakah anak cukup ditangani oleh guru di sekolah saja atau perlu melibatkan pihak atau ahli yang berkompeten. Klasifikasi, 
yaitu kegiatan memilah-milah mana anak dengan gangguan emosi dan perilaku yang memerlukan penanganan lebih lanjut dan mana yang langsung dapat mengikuti pelayanan pendidikan khusus di kelas regular (Awwad, 2015; Dermawan, 2018; Rahayu, 2015). Perencanaan pembelajaran, yaitu penyusunan program pembelajaran yang diindividualisasikan sesuai dengan setiap jenis dan tingkat anak dengan gangguan emosi dan perilaku hasil klasifikasi. Pemantauan kemajuan belajar, untuk mengetahui keberhasilan program pembelajaran dalam kurun waktu tertentu, serta peninjauan atas kegagalan program serta beberapa aspek yang berkaitan, seperti diagnosis yang tidak tepat, atau pelaksanaan program yang perlu diperbaiki (Agustin, 2017; Arriani, 2017; Persada \& Efendi, 2018).

Langkah-langkah identifikasi ini adalah menghimpun data kondisi seluruh siswa di kelas (berdasar gejala yang nampak pada siswa) dengan menggunakan instrumen identifikasi. Menganalisis data dan mengklasifikasi anak untuk menemukan anak yang tergolong anak dengan gangguan emosi dan perilaku serta mencatat temuan berdasarkan gejala emosi dan perilaku, kemudian memisahkannya dengan siswa biasa. Mengadakan pertemuan konsultasi dengan kepala sekolah untuk saran-saran penyelesaian dan tindak lanjut. Menyelenggarakan pertemuan kasus (case conference) mengenai temuan identifikasi untuk mendapat tanggapan mengenai langkah-langkah setelah proses ini. Pertemuan ini dikoordinasikan oleh Kepala Sekolah dan melibatkan dewan guru, orangtua siswa, tenaga profesional yang terkait, dan guru pendamping khusus. Menyusun laporan hasil pertemuan kasus secara lengkap dengan perencanaan program untuk anak yang teridentifikasi.

Council for Exceptional Children US (2001) mengidentifikasi keterampilan yang diperlukan guru dalam mengajar anak dengan gangguan emosi dan perilaku (Weiss dalam Hallahan dan Kauffmann, 2006), yakni mengetahui strategi pencegahan dan intervensi bagi individu yang beresiko mengalami gangguan emosi dan perilaku. Menggunakan variasi teknik yang tidak kaku dan keras untuk mengontrol tingkah laku target dan menjaga atensi dalam pembelajaran. Menjaga rutinitas pembelajaran dengan konsisten, dan terampil dalam problem solving dan mengatasi konflik. Merencanakan dan mengimplementasikan reinforcement secara individual dan modifikasi lingkungan dengan level yang sesuai dengan tingkat perilaku. Mengintegrasikan proses belajar mengajar (akademik), pendidikan afektif, dan manajeman perilaku baik secara individual maupun kelompok. Melakukan asesmen atas tingkah laku sosial yang sesuai dan problematik pada siswa secara individual.

Setelah melakukan proses identifikasi maka guru dapat menentukan model layanan pendidikan bagi anak berkebutuhan khusus dengan gangguan emosional dan perilaku. Adapun beberapa bentuk layanan pendidikan untuk anak dengan gangguan emosional dan perilaku yaitu:

\section{Layanan Pendidikan Segregrasi}

Sistem layanan pendidikan segregasi adalah sistem pendidikan yang terpisah dari sistem pendidikan anak normal. Pendidikan anak berkebutuhan khusus melalui sistem segregasi maksudnya adalah penyelenggaraan pendidikan yang dilaksanakan secara khusus, dan terpisah dari penyelenggaraan pendidikan untuk anak normal. ada empat bentuk penyelenggaraan pendidikan dengan sistem segregasi, yaitu: sekolah luar biasa untuk tunalaras (slb-e), sekolah luar biasa untuk tunalaras (slb-e), berasrama kelas jauh/kelas kunjung, dan sekolah dasar luar biasa (sdlb) (Agustin, 2017; Arriani, 2017; Fridayanthie, 2016a; Indonesia \& Barat, 2019; Nugroho \& Mareza, 2016; Persada \& Efendi, 2018; Wathoni, 2013).

Bagi Anak dengan gangguan emosi dan perilaku yang perlu dipisah belajarnya dengan anak yang lain karena kenakalannya cukup berat atau merugikan anak sebayanya. Sistem pengajarannya lebih mengarah ke sistem individualisasi. Sekolah Luar Biasa Berasrama (SLB-E) merupakan bentuk sekolah luar biasa yang dilengkapi dengan fasilitas asrama sehingga anak dengan gangguan emosi dan perilaku akan tinggal diasrama. Pada SLB berasrama, terdapat kesinambungan program pembelajaran antara yang ada di sekolah dengan di asrama, sehingga asrama merupakan tempat pembinaan setelah anak di sekolah. Selain itu, SLB berasrama merupakan pilihan sekolah yang sesuai bagi anak dengan 
gangguan emosi dan perilaku yang berasal dari luar daerah karena mereka terbatas fasilitas antar jemput.

Kelas jauh atau kelas kunjung adalah lembaga yang disediakan untuk memberi pelayanan pendidikan bagi anak berkebutuhan khusus yang tinggal jauh dari SLB atau SDLB. Penyelenggaraan kelas jauh atau kelas kunjung merupakan kebijaksanaan pemerintah dalam rangka menuntaskan wajib belajar serta pemerataan kesempatan belajar. Anak dengan gangguan emosi dan perilaku tersebar di seluruh pelosok tanah air, sedangkan sekolah-sekolah yang khusus mendidik mereka masih sangat terbatas di kota/kabupaten. Oleh karena itu, dengan adanya kelas jauh/kelas kunjung ini diharapkan layanan pendidikan bagi anak dengan gangguan emosi dan perilaku semakin luas. Dalam penyelenggaraan kelas jauh/kelas kunjung menjadi tanggung jawab SLB terdekatnya. Tenaga guru yang bertugas di kelas tersebut berasal dari guru SLB-SLB di dekatnya. Mereka berfungsi sebagai guru kunjung (itenerant teacher). Kegiatan administrasinya dilaksanakan di SLB terdekat tersebut.

Dalam rangka menuntaskan kesempatan belajar bagi anak berkebutuhan khusus, salah satunya anak dengan gangguan emosi dan perilaku maka pemerintah menyelenggarakan Sekolah Dasar Luar Biasa (SDLB). Tenaga kependidikan di SDLB terdiri dari kepala sekolah, guru untuk anak tunalaras, guru agama, dan guru olahraga. Selain tenaga kependidikan, di SDLB dilengkapai dengan tenaga ahli yang berkaitan dengan kelainan mereka antara lain dokter umum, dokter spesialis, fisiotherapis, psikolog, speech therapist, audiolog. Selain itu ada tenaga administrasi dan penjaga sekolah. Kurikulum yang digunakan di SDLB adalah kurikulum yang digunakan di SLB untuk tingkat dasar yang disesuikan dengan kekhususannya. Kegiatan belajar dilakukan secara individual, kelompok, dan klasikal. Pendekatan yang dipakai juga lebih ke pendekatan individualisasi.

\section{Layanan Pendidikan Terpadu atau Terintegrasi}

Bentuk layanan pendidikan terpadu/integrasi adalah sistem pendidikan yang memberikan kesempatan kepada anak berkebutuhan khusus dengan gangguan emosi dan perilaku untuk belajar bersama-sama dengan anak biasa (normal) di sekolah umum (Khusus et al., 2015; Noviandari \& Huda, 2018; Nuraini, 2013). Dengan demikian, melalui sistem integrasi anak dengan gangguan emosi dan perilaku bersama-sama dengan anak normal belajar dalam satu atap. Sistem pendidikan integrasi disebut juga sistem pendidikan terpadu, yaitu sistem pendidikan yang membawa anak dengan gangguan emosi dan perilaku kepada suasana keterpaduan dengan anak normal. Keterpaduan tersebut dapat bersifat menyeluruh, sebagaian, atau keterpaduan dalam rangka sosialisasi.

Pada sistem keterpaduan secara penuh dan sebagian, jumlah anak berkebutuhan khusus dengan gangguan emosi dan perilaku dalam satu kelas maksimal $10 \%$ dari jumlah siswa keseluruhan. Untuk membantu kesulitan yang dialami oleh anak dengan gangguan emosi dan perilaku, di sekolah terpadu disediakan Guru Pembimbing Khusus (GPK). GPK dapat berfungsi sebagai konsultan bagi guru kelas, kepala sekolah, atau anak dengan gangguan emosi dan perilaku itu sendiri. Selain itu, GPK juga berfungsi sebagai pembimbing di ruang bimbingan khusus atau guru kelas pada kelas khusus. Terdapat tiga bentuk keterpaduan dalam layanan pendidikan bagi anak berkebutuhan khusus dengan gangguan emosi dan perilaku yaitu bentuk kelas biasa, kelas biasa dengan ruang bimbingan khusus bentuk kelas khusus.

Dalam bentuk keterpaduan ini anak berkebutuhan khusus dengan gangguan emosi dan perilaku belajar di kelas biasa secara penuh dengan menggunakan kurikulum biasa. Oleh karena itu sangat diharapkan adanya pelayanan dan bantuan guru kelas atau guru bidang studi semaksimal mungkin dengan memperhatikan petunjuk-petunjuk khusus dalam melaksanakan kegiatan belajar mengajar di kelas biasa. Bentuk keterpaduan ini sering juga disebut keterpaduan penuh. Dalam keterpaduan ini guru pembimbing khusus hanya berfungsi sebagai konsultan bagi kepala sekolah, guru kelas/guru bidang studi, atau orangtua anak berkebutuhan khusus. Seagai konsultan, guru pembimbing khusus berfungsi sebagai penasehat mengenai kurikulum, maupun permasalahan dalam mengajar anak berkebutuhan khusus. Oleh karena itu perlu disediakan ruang konsultasi untuk guru 
pembimbing khusus, pendekatan, metode, cara penilaian yang digunakan pada kelas biasa ini tidak berbeda dengan yang digunakan pada sekolah umum.

Pada keterpaduan ini, anak berkebutuhan khusus dengan gangguan emosi dan perilaku belajar di kelas biasa menggunakan kurikulum biasa serta mengikuti pelayanan khusus untuk mata pelajaran tertentu yang tidak dapat diikuti bersama dengan anak normal. Pelayanan khusus tersebut diberikan di ruang bimbingan khusus oleh guru pembimbing khusus (GPK), dengan menggunakan pendekatan individu dan metode peragaan yang sesuai. Untuk keperluan tersebut, di ruang bimbingan khusus dilengkapi dengan peralatan khusus untuk memberikan latihan dan bimbingan khusus. Keterpaduan pada tingkat ini sering disebut juga keterpaduan sebagian.

Dalam keterpaduan ini anak berkebutuhan khusus dengan gangguan emosi dan perilaku mengikuti pendidikan sama dengan kurikulum di SLB secara penuh di kelas khusus pada sekolah umum yang melaksanakan program pendidikan terpadu. Keterpaduan ini disebut juga keterpaduan lokal bangunan atau keterpaduan yang bersifat sosialisasi. Pada tingkat keterpaduan ini, guru pembimbing khusus berfungsi sebagai pelaksana program di kelas khusus. Pendekatan, metode, dan cara penilaian yang digunakan adalah pendekatan, metode, dan cara penilaian yang biasa digunakan di SLB. Keterpaduan pada tingkat ini hanya bersifat fisik dan sosial, artinya anak berkebutuhan khusus dapat dipadukan untuk kegiatan yang bersifat non akademik, seperti olahraga, keterampilan, juga sosialisasi pada waktu jam-jam istirahat atau acara lain yang diadakan oleh sekolah.

\section{Pendidikan Inklusif}

Beberapa penelitian juga mengungkapkan bahwa pendidikan yang tepat untuk anakanak berkebutuhan khusus dengan gangguan emosi dan perilaku ini adalah pendidikan Inklusif. Pendidikan inklusif ini sendiri merupakan pendidikan tidak berpihak pada homogenitas sekelompok siswa. Dengan kata lain secara implikasi pendidikan ini merupakan pendidikan yang tidak mengenal penyetaraan baik kemampuan akademik maupun non akademik bagi calon siswa, dan tidak pula mengenal istilah 'mengeluarkan' siswa dari sekolah karena bermasalah (Arriani, 2017; Aziz, 2014; Dermawan, 2018; Fridayanthie, 2016b; Indonesia \& Barat, 2019). Pendidikan ini memungkinkan siswa untuk belajar bersama dengan anak normal lainnya, dan menyatakan penerimaan sepenuhnya pada anak berkebutuhan khusus, termasuk didalamnya anak-anak dengan ganggaun emosi dan perilaku. Beberapa hal yang sebenarnya menyebabkan pendidikan inklusif banyak direkomendasikan untuk pendidikan berkebutuhan khusus dengan gangguan emosi dan perilaku yaitu pendidikan inklusif mau merekrut semua jenis siswa, pendidikan inklusif menghindarkan semua aspek negatif seperti labeling, pendidikan inklusif selalu melakukan checks dan balances. Pendidikan ini menyatakan bahwa anak yang beresiko tidak disukai bahkan mengalami penolakan lingkungan (Farell, 2008) sebagai sesuatu yang khas menimpa anak berkebutuhan khsus dengan gangguan emosi dan perilaku.

Labeling merupakan hal yang dapat memberikan dampak buruk pada mereka yang diberi label negatif, dan sering kali mereka yang mendapat label adalah anak-anak kebutuhan khusus (Agustin, 2017; Fridayanthie, 2016b; Praptiningrum, 2012; Wathoni, 2013). Dengan penerimaan pada anak kebutuhan khusus dan normal dalam satu lingkungan belajar, tentu perasaan inferioritas tersebut bisa dihindarkan. Secara kongkrit, pendidikan inklusif berusaha menghindari label negatif dengan mengubah label yang ada dimasa lalu menjadi lebih positif dimasa kini. Pendidikan inklusif bukan hanya diatur oleh pihak formal, pemerintah dan sekolah sebagai penyelenggara. Dimana pendidikan ini memerlukan keseimbangan terkait pihak-pihak yang berkaitan dengan siswa itu sendiri, seperti orangtua, masyarakat, serta ahli terkait dengan karakteristik khusus (Farrell, 2008). Dalam konteks pendidikan anak berkebutuhan khusus dengan gangguan emosi dan perilaku, checks dan balances sangat berarti. Peran sekolah sebagai penyedia layanan pendidikan akan terbantu dengan kerjasama yang baik dari orangtua siswa sebagai guru sekaligus diagnostician gangguan emosi dan perilaku anak di rumah, komite sekolah yang juga dapat berperan dalam advokasi atas berbagai resiko gangguan emosi dan perilaku yang ditimbulkan anak, 
dan ahli psikiatri serta psikolog sebagai penentu dan pemberi treatmen klinis gangguan emosi dan perilaku.

Sejalan dengan pendidikan Inklusif, hal yang juga penting untuk pendidikan anak dengan gangguan emosi dan perilaku adalah welcoming school (Anggriana \& Trisnani, 2016; Nugroho \& Mareza, 2016; Persada \& Efendi, 2018; Rahayu, 2015). Ketika komunitas sekolah, seperti guru dan anak-anak bekerja bersama-sama untuk meminimalkan hambatan yang dihadapi anak dalam belajar dan mempromosikan keikutsertaan dari seluruh anak di sekolah, maka ini merupakan salah satu ciri dari sekolah yang ramah (welcoming school). Di Sekolah yang Ramah (welcoming schools) semua komunitas sekolah mengerti bahwa tujuan pendidikan adalah sama untuk semua, yaitu semua murid mempunyai hak untuk merasa aman dan nyaman (to be save and secure), untuk mengembangkan diri (to develop a sense of self), untuk membuat pilihan (to make choices), untuk berkomunikasi (to communicate), untuk menjadi bagian dari komunitas (to be part of a community), untuk mampu hidup dalam situasi dunia yang terus berubah (live in a changing world), untuk menghadapi banyak transisi dalam hidup, dan untuk memberi kontribusi yang bernilai (to make valued contributions).

Pada akhirnya, setiap model layanan pendidikan yang dikembangkan akan berhasil jika guru sebagai pengajar sekaligus pendamping siswa harus mampu mengkondisikan supaya kebutuhan pendidikan bagi masing-masing anak terpenuhi dengan baik. Seperti yang dikemukakan oleh Tirtayani (2017), bahwa terdapat beberapa hal mendasar yang harus dilakukan oleh seorang guru terhadap anak berkebutuhan khusus yaitu: (1) menghilangkan persepsi negatif, artinya dari awal guru tidak boleh beranggapan bahwa anak tersebut tidak akan mampu mengikuti pembelajaran justru diberikan motivasi khusus dengan strategi yang tepat; (2) upaya monitoring peran, guru harus senantiasa menyadari bahwa pengelolaan pembelajaran yang dilakukan adalah berbeda dengan pembelajaran pada umumnya karena peserta didik yang memiliki kebutuhan khsus akan sangat berbeda perlakuan-perlakuan yang diberikan dibandingkan anak dengan kondisi normal; (3) berefleksi dan memiliki harapan pada peserta didiknya, apabila peserta didik belum mampu mencapai tujuan pembelajaran maka guru juga harus melakukan refleksi terhadap metode dan startegi yang dirancang serta menaruh harapan tersendiri pada peserta didik agar kelak mereka mampu memiliki kemampuan untuk pencapaian hasil belajar yang lebih baik lagi.

\section{Simpulan dan Rekomendasi}

Berdasarkan hasil penelitian dapat disimpulkan beberapa hal. Pertama, anak berkebutuhan khusus dengan gangguan emosi dan perilaku diartikan sebagai anak yang mengalami kesulitan dalam penyesuaian diri dan bertingkah laku tidak sesuai dengan norma-norma yang berlaku dalam lingkungan kelompok usia maupun masyarakat pada umumnya, sehingga merugikan dirinya maupun orang lain, dan karenanya memerlukan pelayanan pendidikan khusus demi kesejahteraan dirinya maupun lingkungannya. Kedua, karakteristik anak dengan gangguan perilaku dan emosi yaitu inteligensi dan prestasi belajar, karakteristik sosial dan emosi. agresif, acting-out behavior (externalizing), dan immature, withdrawl behavior (internalizing). Ketiga, beberapa faktor yang menyebabkan terjadinya gangguang emosi dan perilaku yaitu faktor biologi, faktor lingkungan atau keluarga, faktor sekolah, dan faktor masyarakat. Keempat, beberapa pendekatan yang dapat dilakukan dalam usaha mengatasi permasalahan anak dengan gangguan emosi dan perilaku yaitu: pendekatan biomedis, pendekatan psikodinamik, pendekatan perilaku, pendekatan pendidikan, dan pendekatan ekologi. Kelima, model layanan pendidikan bagi anak berkebutuhan khusus dapat dikelompokkan menjadi 3 kelompok besar, yaitu: bentuk layanan pendidikan segregrasi; bentuk layanan pendidikan terpadu/integrasi, dan pendidikan inklusif.

Berdasarkan simpulan tersebut dapat dikemukakan saran yaitu model layanan penidikan yang dirancang harus mampu memfasilitasi berbagai kebutuhan yang melekat pada anak berkebutuhan khusus dengan gangguan emosi dan perilaku. Hal tersebut hanya akan bisa tercapai jika mampu mensinergikan berbagai komponen dalam pendidikan seperti 
guru, fasilitas penunjang kreativitas anak, kurikulum, lingkungan belajar yang mampu memotivasi anak untuk meningkatkan motivasi dan hasil belajar. Selain itu mengenali karakteristik masing-masing anak juga menjadi suatu hal yang sangat penting, karena karakteristik anak yang berbeda-beda juga memerlukan metode dan pendekatan yang digunakan dalam proses pendampingan kegiatan pembelajaran juga berbeda-beda. Dengan demikian tujuan dari pembelajaran dapat tersampaikan dengan baik.

\section{Daftar Pustaka}

Agustin, I. (2017). Manajemen Pendidikan Inklusi Di Sekolah Dasar Sumbersari 1 Kota Malang. Education And Human Development Journal, 1(1). Https://Doi.Org/10.33086 /Ehdj.V1i1.290

Anggriana, T. M., \& Trisnani, R. P. (2016). Kompetensi Guru Pendamping Siswa Abk Di Sekolah Dasar. Jurnal Konseling Gusjigang, 2(2), 157-164. Https://Doi.Org/10.24176 /Jkg.V2i2.702

Arriani, F. (2017). Kebijakan Layanan Pendidikan Untuk Anak Berkebutuhan Khusus (Abk) Di Satuan Pendidikan Anak Usia Dini (Paud). AWLADY: Jurnal Pendidikan Anak, 3(1), 1-18. Https://Doi.Org/10.24235/Awlady.V3i1.1217

Awwad, M. (2015). Urgensi Layanan Bimbingan Dan Konseling Bagi Anak Berkebutuhan Khusus. Al-Tazkiah: Jurnal Bimbingan Dan Konseling Islam, 4(1), 46-64.

Aziz, S. (2014). Pendidikan Seks Bagi Anak Berkebutuhan Khusus. Jurnal Kependidikan, li(Hal 140), 182-204.

Bower, Gordon, H. Ersnest. 1981, Theoriest Of Learning. Engle Wood Clift: Prentice Hall

Farrel, Michael (2008). Inclusion At The Crossroads, Special Education-Concept And Values.Usa: David Fulton Publisher.

Dermawan, O. (2018). Strategi Pembelajaran Bagi Anak Berkebutuhan Khusus Di Slb. Psympathic: Jurnal Ilmiah Psikologi, 6(2), 886-897. Https://Doi.Org/10.15575/ Psy.V6i2.2206

Fridayanthie, E. Wida. (2016a). Manfaat Program Pendidikan Inklusi Untuk Aud Nurul. Jurnal Pendidikan Anak, 3(1), 56. Https://Doi.Org/Https://Doi.Org/10.3929/Ethz-B-000238666

Fridayanthie, E. Wida. (2016b). Pengembangan Model Deteksi Dini Anak Berkebutuhan Khusus (Abk) Pada Tingkat Pendidikan Anak Usia Dini (Paud) Di Kota Malang. Jurnal Ilmiah Psikologi Terapan, 3(1), 56. Https://Doi.Org/Https://Doi.Org/10.3929/Ethz-B000238666

Hallahan, D.P. \& Kauffman, J.M. (1988). Exceptional Children: Introduction To Special Education. $4^{\text {th }}$ Ed. New Jersey: Prentice Hall.

Hallahan, D.P. \& Kauffman, J.M. (2006). Exceptional Learners: Introduction To Special Education 10th Ed. USA: Pearson.

Indonesia, U. P., \& Barat, J. (2019). Model Manajemen Pendidikan Life Skill Pada Anak Berkebutuhan Khusus. Jurnal Penelitian Pendidikan, 18(3), 306-317.

Khusus, B., Di, A. B. K., \& Jawa, P. (2015). Evaluasi Pendidikan Inklusif Bagi Anak Berkebutuhan Khusus (Abk) Di Provinsi Jawa Tengah. Jurnal Penelitian Pendidikana \& A (Semarang), 32(2), 119-126. Https://Doi.Org/10.15294/Jpp.V32i2.5057

Murniarti, E., \& Anastasia, N. Z. (2016). Pendidikan Inklusif Di Tingkat Sekolah Dasar: Konsep, Implementasi, Dan Strategi. Jurnal Dinamika Pendidikan, 9(1), 9-18.

Noviandari, H., \& Huda, T. . (2018). Peran Sekolah Dalam Pendidikan Anak Berkebutuhan Khusus Di Sdllb Pgri Bangorejo Banyuwangi. Jurnal Psikologi, 5(1), 29-37.

Nugroho, A., \& Mareza, L. (2016). Model Dan Strategi Pembelajaran Anak Berkebutuhan Khusus Dalam Setting Pendidikan Inklusi. Jurnal Pendidikan Dasar Perkhasa, 2(2).

Nuraini. (2013). Peran Orang Tua Dalam Penerapan Pendidikan. Jurnal Kependidikan, 03(01), 63-86.

Oktaviana, M \& Wimbarti, S. (2014) Validasi Klinik Strenghts And Difficulties Questionnaire (SDQ) Sebagai Instrumen Skrining Gangguan Tingkah Laku. Jurnal Psikologi 41(1) $101-114$

Persada, H. J., \& Efendi, M. (2018). Studi Kasus Implementasi Layanan Pendidikan Inklusif Di Kota Madiun. Jurnal Ortopedagogia, 4(1), 7-11. Https://Doi.Org/10.17977/ 
Um031v4i12018p007

Praptiningrum, N. (2012). Fenomena Penyelenggaraan Pendidikan Inklusif Bagi Anak Berkebutuhan Khusus. In Jpk: Jurnal Pendidikan Khusus (Vol. 7, Issue 2). Https://Doi.Org/10.21831/Jpk.V7i2.774

Rohmawati, Ulva Badi. 2017. Peran Keluarga Dalam Mengurangi Gangguan Emosional Pada Anak Berkebutuhan Khusus. Jurnal Pendidikan Islam. Volume II Nomor 2

Rafikayati, Ana, \& Jauhari, M. N. (2018). Keterlibatan Orangtua Dalam Penanganan Anak Berkebutuhan Khusus. Jurnal Abadimas Adi Buana, 2(1), 55-64. Https:// Doi.Org/10.36456/Abadimas.V2.I1.A1636

Rahayu, S. M. (2015). Memenuhi Hak Anak Berkebutuhan Khusus Anak Usia Dini Melalui Pendidikan Inklusif. In Jurnal Pendidikan Anak (Vol. 2, Issue 2). Https://Doi.Org/10.21831/Jpa.V2i2.3048

Sunardi. (1996). Ortopedagogik Anak Tunalaras I, Depdiknas Dikti.

Tirtayani, Luh Ayu. 2017. Upaya Pendampingan Anak Berkebutuhan Khusus Pada Lembaga-Lembaga PAUD Di Singaraja, Bali. Proyeksi, Vol. 12(2).

Wathoni, K. (2013). Implementasi Pendidikan Inklusi Dalam Pendidikan Islam. Ta'allum: Jurnal Pendidikan Islam, 1(1). Https://Doi.Org/10.21274/Taalum.2013.1.01.99-109

Wati, E. (2014). Manajemen Pendidikan Inklusi Di Sekolah Dasar Negeri 32 Kota Banda Aceh. Jurnal IImiah Didaktika, 14(2), 368-378. Https://Doi.Org/10.22373/Jid.V14i2.508 